\title{
Old Capitol Library: \\ Its History, Contents, and Restoration
}

Martha Esbin

ON JUNE 12, 1838, THE SECOND SESSION of the Twenty-fifth Congress of the United States declared that "from and after the third day of July next," the territory of Wisconsin be divided and the territorial government of Iowa established. The passage of the Organic Act created with one stroke lowa Territory and its first "constitution."

Luckily for Iowa, the federal legislators valued books highly, for they not only established Iowa's first library, but funded it handsomely. The Organic Act, Section 18, states that:

... the sum of five thousand dollars by and the same is hereby appropriated out of any money in the treasury not otherwise appropriated, to be expended by and under the direction of the governor of the said territory of Iowa, in the purchase of a library to be kept at the seat of government for the accommodation of the governor, legislative assembly, judges, secretary, marshal, and attorney of said territory, and such other persons as the governor and legislative assembly shall direct.'

The appointed governor of Iowa Territory, Robert Lucas, wasted no time in carrying out this directive. In less than three weeks, he compiled a list of items for the library, and turned it over to Edward Lucas, a Cincinnati bookseller!

On November 12,1838, in the governor's first annual message, he said:

Previous to leaving Ohio, in June last, (with the assistance of several literary friends.) I made out a catalogue of such standard works as are deemed most important as the foundation of a public library, and put

'U.S. Statute II, Chapter 96, Sec. 18, United States Statutes at Large, 5 , 240. 
catalogue into the hands of an agent in Cincinnati to make the purchase for me. ${ }^{2}$

One of Lucas' "literary friends" was Theodore S. Parvin, who would become Iowa's first territorial librarian. Parvin said that in 1839 he bought miscellaneous books in Baltimore, and that McLain* selected law books. ${ }^{3}$

Several letters in the Robert Lucas papers at the State Historical Society of Iowa shed light on the early selection and acquisition of books. Probably the most important of these is one dated September 6, 1838, from Robert Lucas to Edward Lucas. The governor noted Edward Lucas' suggestions for additions in the fields of law and medicine, and approved them. Robert Lucas then suggested the inclusion of works on Indians, a complete set of elementary school books, theological works of "all denominations of Christians, as well as the Mahomitan Koran," and township plats of all the "surveys lands in this Terity." ${ }_{4}$

It seems that the $\$ 5,000$ grant was not totally used for the library, because the letter continues: "Sir, I am perfectly willing to submit to your judgment in filling the catalogue of Books for the Library to the amt. of $\$ 4,000$ including your per cent." 5

Between August and October of 1838, there were four letters between Governor Lucas and E. S. Haines, Surveyor General of Cincinnati. In August, Haines suggested an enlargement of the list of law books. In September, Haines acknowledged receipt of $\$ 4,000$ for books. Finally, on October 19, Haines reported that: “. . . your list of books for Mr. Lucas and Co. has been made as perfect as the amount $(\$ 4,000)$ would purchase." 6

Suggestions for the library came from George Templeman? and Samuel Williams. ${ }^{8}$ Parvin, who was in Cincinnati, reported

${ }^{2} 1838$ Iowa Council Journal, 13.

*John McLean of Ohio, 1829-1861, who was to become a Justice of the United States Supreme Court.

${ }^{3}$ Edward H. Stiles, Recollections and Sketches of Notable Lawyers and Public Men of Early Iowa (Des Moines: Homestead Publishing Company, 1916), 570.

'Letter from Robert Lucas to Edward Lucas, September 6, 1838, Robert Lucas Papers, State Historical Society of Iowa (hereafter cited as RLP).

'Ibid.

${ }^{6}$ Letter from E. S. Haines to Robert Lucas, August 14, 1838; Lucas to Haines, September 6, 1838; Haines to Lucas, September 28, 1838; and Haines to Lucas, October 19, 1838, RLP.

'Letter from George Templeman to Lucas, September 20, 1838, RLP.

'Letter from Samuel Williams to Lucas, November 14, 1838, RLP. 
on the first of October that some of the books were boxed and were waiting for the river to rise. He also mentioned that $\mathrm{Mr}$. Lucas "will start East this week and will procure the remainder as soon as possible.",

By the end of November, two boxes containing a total of 238 volumes were shipped aboard the steamboat H. S. Kinney. "We expect in a few days to ship you more boxes . ." ${ }^{10}$ On or about the ninth of April, 1839, most of the books arrived in Burlington. ${ }^{11}$ Delay caused by low waters had extended the transportation time to over four months!

On April 10, Theodore Parvin, private secretary to Governor Lucas, was commissioned as librarian. Parvin immediately devised a simple classification scheme, and arranged the books in alphabetical order in walnut cases. ${ }^{12}$ The fruit of his labor was the "Catalogue of the lowa Territorial Library," printed by James G. Edwards in Burlington in 1839. The Iowa Masonic Library in Cedar Rapids, which was founded by Mr. Parvin, possesses a copy. The catalogue is 4 inches by 6 and 1/8 inches, 18 pages in length, and has a blue cover. On the last page are the words " 1568 vols., $\$ 3.80$ cash per vol.," possibly in Parvin's handwriting.

There is no doubt that Parvin was a most remarkable man: a collector, curator, lawyer, professor, and public servant. Johnson Brigham, state librarian from 1898 to 1936 , even called him the "Nestor of Iowa librarians." 13

One fine source of information about Parvin is Joseph E. Morcombe's The Life and Labors of Theodore Sutton Parvin, published in Clinton, Iowa, in 1906. Another source is Parvin's diaries, which are located in the Iowa Masonic Library. It is ironic to note that Parvin was probably not paid for his efforts. In a lengthy letter (undated) to the Committee on Expenditures of the House of Representatives, Parvin said that he:

entered upon the duties of the office by superintending the fitting up of the Library Room and making out the Catalogue of the Books which it

\footnotetext{
${ }^{9}$ Letter from Theodore Parvin to Lucas, October 1, 1838, RLP. RLP.

${ }^{10}$ Letter from Edward Lucas and Co. to Robert Lucas, November 20, 1838 ,

"Luella Margaret Wright, "Iowa's Oldest Library," Iowa Journal of History and Politics (1940), 38, 412.

"IIbid., 413.

'3ohnson Brigham, "Iowa's Pioneer Librarian," Iowa Library Quarterly (1901), 1, 55 .
} 
contained all of which being done and before the Library was finally opened or the Catalogue published ...

He concluded with a request for $\$ 400$, of which $\$ 100$ was for "Services rendered in Superintending Library \& as Librarian." He reminded the committee that for all his work he had "never yet received the first farthing- " 14

On January 5, 1842, Parvin's petition for compensation was presented to the fourth legislative assembly by Serranus C. Hastings. It was referred to the committee on claims. On February 2, the:

Said committee have had the same under consideration, and are of opinion that the Legislature have no right to authorize the Secretary of the Territory to appropriate any money, now in his hands, to pay said claim, and asked to be discharged from further consideration of the subject.

On motion, the committee were discharged ... is

The Parvin catalogue may be the only one of this early period, despite the fact that in the Historical Sketch of the Iowa State Library (1875), appear these words: "The catalogue of the original collection, prepared by Judge McLean, cannot be found, although one hundred copies were ordered, by the second legislative assembly, to be printed." 16

Brigham disputes the McLean theory in his history of Iowa's first library, published in 1912 and 1913. He definitely credits Parvin with the making of the original catalogue. ${ }^{17}$ The Journal of the second legislative assembly refers only twice to the catalogue. On Monday afternoon, November 18, 1839, the standing committee on the library was "instructed to wait on his excellency Gov. Lucas, and respectfully request him to furnish them with a catalogue of the books composing the Territorial Library, together with the original inventory of purchase . . "18

Then on the morning of November 21, 1839, Jesse D. Payne of the library committee reported:

That it has been the pleasure of His Excellency Governor Lucas to comply with the same, that a catalogue of Books is herewith submitted for

${ }^{14} \mathrm{~T}$. S. Parvin, undated letter, Miscellaneous Letters, State Historical Society of lowa.

is 1841 Iowa Council Journal, 54, 145.

${ }^{16}$ Iowa State Library, Des Moines, Report, 1875, 9.

"Johnson Brigham, "Pioneer History of the Territorial and State Library of lowa," Annals of Iowa (1912), 10, 491.

${ }^{18} 1840$ Iowa Council Journal, 31. 
the inspection of the Council, and that the original Invoices are in possession of the committee, which his Excellency requests may be returned. as they will be needed in settling with his agent.*19

Just two weeks before, on November 5, 1839, the governor had delivered his second annual message. Lucas disclosed that the appropriation had been expended, and the books received. He recommended a law regarding the appointment of the librarian and defining the librarian's duties. He also suggested a small annual appropriation for periodicals and other books.

Parvin's name was never mentioned. Lucas referred to lowa's second territorial librarian, Charles Weston, as being appointed "pro tem" on October 18, 1839. Lucas continued:

There being no provision made by law for paying the rent of the library room, and other incidental expenses connected therewith, Mr. John S.

David, the proprietor of the building, agreed to fit up the room, and wait the pleasure of the Legislature to make him such an allowance as they might deem reasonable. ${ }^{20}$

Now, Charles Weston, a lawyer from New York, who had come to Burlington in 1837 , temporarily took over the reins. He held the post from October 18, 1839, until January 24, 1840. On this date, Morgan Reno became the third and last territorial librarian. Reno was in the banking business, and was also second treasurer of the territory and the first state treasurer. Under Reno's leadership, the library was moved to Iowa City in 1841. In his second annual report, he said:

I am happy to inform you, that the Territorial Library is now arranged and in good order in this city. By care and attention in packing, the books have arrived here uninjured. ${ }^{21}$

And Reno compiled the library's second catalogue. This was printed by A. P. Wood in Iowa City in 1845 . A copy may be found in the Iowa Masonic Library. It is 18 pages in length, and is just slightly smaller than the 4 by 6 and $1 / 8$ inch 1839 catalogue. Comparing the two catalogues, we find fewer titles in the 1845 edition. The Laws of Iowa are listed in the 1839 catalogue, but

*Although these two references raise the third possibility that Robert Lucas himself prepared a catalogue, it seems more likely that the governor handed over Parvin's list to the committee.

"Ibid., 36.

${ }^{20} 1839$ Iowa Council Journal, 194.

${ }^{2}$ Iowa Territorial Library, Iowa City, Report, 1841; Iowa State Department of History and Archives; 4th Terr. Assembly, 1841, Six 23. 
not the 1845. The works of Thomas Moore are gone. Charles Bucke's On the Beauties. Harmonies, and Sublimities of Nature ... is missing. James Hervey's Meditations has disappeared along with five maps and eight medical books. Were the legislators amateur doctors?

In 1846, the year following the publication of the library's second catalogue, Iowa became a state. Four librarians were to serve as state librarian while the state library was housed at Old Capitol in lowa City. In 1846, Lemuel B. Patterson was appointed; in 1851, Israel Kister; in 1852, Martin L. Morris, and in 1855, John Pattee.

What was the atmosphere like in the Old Capitol Library? Johnson Brigham called it "the day of candles and goose quills," ${ }^{22}$ describing the use of tallow candles, wafers and sealingwax, and pepper-boxes of sand to absorb ink.

In 1847 , the librarian was paid a salary of $\$ 150$ annually. An act passed in 1840 setting the salary at $\$ 210$ was repealed at this time. The librarian did have "authority to appoint an assistant ... provided, however, that said assistant shall be paid out of the salary of the librarian." 23

According to Ada North, state librarian from 1871 to 1878 , at the salary of $\$ 150$, little care was given to the library. She recounts a legend that "for several years the sole guardian of the library was the key to the door of the room containing it, which was generally left, hanging conveniently near, for the unrestricted use of any person desiring access to the books." 24

We know there was some excitement in the library. In the 1840 s, after editor Jesse Williams criticized legislator George $\mathrm{H}$. Walworth, a fight ensued in the library. "Being a powerful man, Walworth soon had his opponent upon the floor where he proceeded to give him so thorough a beating that blood flowed freely and began to form a pool on the carpet." Secretary of the Territory O. H. W. Stull, who had purchased it, asked them why they were spoiling his carpet, and ejected the "scoundrels." 25

${ }^{22}$ Johnson Brigham, "Pioneer History . . .," 506-508.

${ }^{23}$ Laws of Iowa. Chapter 48, Secs. 12, 16 and 20. Iowa General Assembly, Acts and Resolutions, 1847 (1913 reprint), p. 59.

${ }^{24}$ lowa State Library, 1875 Report, p. 13.

${ }^{25}$ John C. Parish. "Perils of a Pioneer Editor," Palimpsest (1921), 2, 237. 
In the following decade, to prevent a different kind of excitement, the legislature passed a law declaring that the library room could be used only for library purposes. In the margin of the law book appear the words: "Library not to be used for balls." 26

This same law had two other very important sections. The librarian was to prepare a catalogue before April 1, 1856,* and the books were to be labeled with a printed label with the words "Iowa State Library," the number of the volume in the catalogue inscribed on that label, and the words "Iowa State Library" written on the bottom of the thirtieth page of each volume. ${ }^{27}$

It was in 1855 that the law requiring identification on the library books was passed. Only two years later, Des Moines became the capital of the state.

In the fall of 1857 the library was brought from Iowa City, in charge of Mr. John Pattee, Auditor of State, who was also librarian. The 3,000 volumes which the library then contained, were deposited in a room prepared for that purpose in the capitol, and shortly after Mr. L. I. Coulter was made librarian. ${ }^{28}$

Toward the end of the nineteenth century, Parvin wrote to state librarian Brigham and compared the 1872 catalogue with the earlier two. He noted that the comparison:

Reveals some facts not so pleasant or creditable to your early predecessors or to the territory and state. Many of the volumes found in the catalogue of 1839 are not catalogued in that of 1845 or 1872 , showing that there were some book-thieves in those days as well as in later years. ${ }^{29}$

\section{The Library's Contents and Authors}

Theodore Parvin divided the contents of the library into fifteen broad subjects. The classifications were: Biography, Education, History, Jurisprudence, Laws, Reports, Medicine, Miscellaneous, Periodical, Poetry, Political, Etc., Science, Etc.. Theological. Voyages and Travels, and Maps.

"Etc." becomes meaningful when you consider that "Science, Etc." contained George Campbell's Philosophy of Rhetoric, John Locke's Essay on Human Understanding, and books on philoso-

${ }^{20}$ Laws of Iowa, Chapter 157, Sec. 19, Iowa General Assembly, Acts. Resolutions and Memorials (1853-55), 4-5, 235.

*This apparently was not done, because the next catalogue that can be found is the first catalogue of the state library, published in $\mathbf{1 8 7 2}$.

${ }^{27}$ Ibid. Chapter 157, Secs. 10 and 11, 233.

${ }^{28}$ Iowa State Library, Des Moines, Report, 1885, 13.

${ }^{29}$ Johnson Brigham, "Iowa's Pioneer Librarian," 56. 
phy and phrenology. Included was the first American work on mineralogy, Parker Cleaveland's An Elementary Treatise on Mineralogy and Geology. Also grouped in this section were books on architecture, botany, topographical drawing, chemistry, and mathematics.

The Biography class boasted the beautiful four volume set of the National Portrait Gallery of Distinguished Americans, published in the years 1834-1839. Along with the portrait engravings, from which many best-known likenesses are derived, are short biographies.

In separate books were the stories of such Americans as Thomas Jefferson, Robert Fulton, Joshua Barney, Aaron Burr, John Paul Jones, Nathanael Greene, Gouverneur Morris, Joseph Story, and Patrick Henry. Other volumes included biographies of Samuel Johnson, Christopher Columbus, Napoleon I, Louis XIV, Benvenuto Cellini, and The Life of Christ by August Neander.

Various views on education were in the library: "popular," "liberal," "practical," "female," "progressive," "home," and "systematic." The "Lancasterian" theory* is represented twice, once with a manual of its teaching system by the English founder, Joseph Lancaster, and with an address by John Griscom entitled Monitorial Instruction.

The collection was strong in history and poetry. These subjects must have seemed compelling and vital and satisfying to the needs of the nineteenth century reader in his small world. They provided intellectual and emotional stimulation which would be hard to match today when we are surrounded by visual entertain. ment and rapid and continual technological change.

There were histories of the United States, and of the states of Ohio, Louisiana, Pennsylvania, New Hampshire, Maryland, Massachusetts, New Jersey, Kentucky, North Carolina, New York, Vermont, and Maine. There were histories of England (ten!), France, Rome, Greece, Mexico, Peru, India, and Scotland. Even a university made the list: there was a history of Harvard. By 1852, 59 titles (168 actual volumes) had been accumulated.

There were 52 poetry titles. One title alone, British Poets, con-

"Lancasterian schools had small classes under "monitors," and discipline was quasi-military. 
sisted of 50 volumes. It would be difficult to give an accurate count of the total volumes, because it may be that some titles were counted twice. Many titles listed separately appeared to be part of the British Poets set.

The poetry was basically pre-1839, and basically British. However, in 1852, Goethe and Longfellow's works were added to the collection. There were one or two volumes of Shakespeare. A reference to "Shakespeare, John'son" in the 1839 catalogue could mean the work of William Shakespeare, edited by Samuel Johnson.

Parvin took treatises, codes, digests, and dictionaries of law, and classified them "Jurisprudence." Seventy-two titles (139 volumes), approximately two-thirds of which are pre-1839, and the others post-1852, represent the works of Joseph Angell, Matthew Bacon, Joseph Chitty, Jean Domat, Simon Greenleaf, Edward Livingston, Samuel von Pufendorf, William Rawle, Joseph Story, Sir Thomas Edlyne Tomlins, Emmerich de Vattel, and others. The first important book on medical jurisprudence published in the United States, Elements of Medical Jurisprudence. by Theodoric Beck, was a part of this group.

There were laws of the United States and thirteen individual states. There were court reports of Great Britain, the United States, and eleven states. It is not surprising that the earlier-established eastern states of New York and Pennsylvania had by far the greatest number of reports.

One really could have been an amateur doctor if you consider the titles contained in "Medicine." There were studies on the nerves, heart, blood, and ear. There were textbooks on the practice of medicine, the treatment of particular diseases, and even a dictionary of "practical" surgery. By 1845 , all three books by William Dewees had disappeared. These were on midwifery, the diseases of females, and "Dewees on practice"-which could be either his treatise on the treatment of children or $A$ Practice of Physic.

For those interested in the mind, the library contained Isaac Ray's Medical Jurisprudence of Insanity, and Benjamin Rush's Medical Inquiries and Observations upon the Diseases of the Mind. The latter book, published in 1812, was one of the earliest volumes of modern psychiatry.

If you were still interested in this particular subject, you might 
check "Miscellaneous," for this is where Robert Burton's Anatomy of Melancholy was placed. Burton, in order to "avoid melancholy," ${ }^{30}$ wrote the book in the early seventeenth century. The Old Capitol Library apparently had a two volume edition published in Philadelphia in 1836.

Also in "Miscellaneous," we find Parent's Friend. The Academician. Chrestomathia (all on education); John Armstrong's Treatise on Agriculture, speeches, statistical works, dictionaries including Noah Webster's first edition (1828), and collected works of Francis Bacon, Benjamin Franklin, Thomas Jefferson, Samuel Johnson, Sir Walter Scott, Daniel Webster, and others.

Looking further, you might be intrigued by Daniel Browne's The Trees of America, or the most famous comic novel ever written, Don Quixote. Or, maybe Giovanni Marana's eight volume Letters of a Turkish Spy would be for you.

The periodical section reflected the temper of the eighteenth and nineteenth centuries: the flowery language, the reviews that attack the character of the author (or philosophize on an entirely different subject) rather than criticize the book, and the contemporary view of many of the same books contained in the Old Capitol Library.

You find a picture of the society which is a revelation because it shows its attitudes and biases as well as its history. Some periodicals were: American Almanac and Repository of Useful Knowledge, American Quarterly Review. Edinburgh Review, Foreign Quarterly Review, Knickerbocker. Methodist Magazine, Niles' Register, North American Review, and Silliman's Journal of Science.

The 34 titles in "Political, Etc." included John Adam's A Defence of the Constitutions of Government of the United States of America: American state papers; the fifth United States census (1830); American Archives; papers of James Madison; Thomas Malthus' essay on population; documents, journals, speeches, and correspondence relating to early American history; and the classic observation of American society, Democracy in America, by Alexis de Tocqueville.

We are reminded of another time when anonymous authors sent letter after letter to newspapers. The political and philoso-

${ }^{30}$ Dictionary of National Biography, 3, 465. 
phical letters of Junius, which were published in the London Public Advertiser regularly for three years, 1769-1772, are collected in a two volume set. The letters of Publius, defending the U.S. Constitution, first appeared in 1788, and are known as the Federalist Papers. Old Capitol Library had just one volume.

Lucas's wish for the Koran was granted. The Bible, Methodist disciplines, sermons, dictionaries, commentaries, concordances, histories, and general treatises were also part of "Theological."

In "Voyages and Travels" were stories of voyages around the world, voyages to specific countries or continents, expeditions within the United States, and sketches of life in Canada (Roughing it in the Bush by Susanna Moodie). Without leaving Iowa City, one could witness and share in the excitements of the opening of new frontiers.

Finally, there were maps of the world, Europe, United States, several states, territories, areas of the United States, cities (Cincinnati, Logansport, Nashville, New Orleans, and Philadelphia), and mail routes.

How was Iowa's first library viewed in the 1840 s and 1850 s? In early November, 1840, Morgan Reno referred to it as small, but "chaste and circumspect." ${ }^{31}$ Later that same month, the committee on the territorial library reported to the legislature that the library was "deficient in many works," requested that the talent of American authors not be neglected, and complained that only one periodical was received. The committee recommended an appropriation of $\$ 500$, and listed desirable additions to the library. The legislators wanted mainly periodicals, but asked for a few books on diverse subjects. ${ }^{32}$

Librarian Reno, in one year's time, lost his calm. In his 1841 report, he said the library was "far in the rear of the literary world" and pleaded for funds so that the library could be "not only a name, but a substance.," ${ }^{33}$

The librarian in 1848, Lemuel B. Patterson, reminded the legislature that:

There has never been an appropriation for the increase of the library; consequently, the only increase, which is very small, arises from an exchange of books among the different states and some books sent by Con-

${ }^{3} 1840$ Iowa Council Journal, 18.

${ }^{32} 1841$ Iowa Council Journal, 45-47.

${ }^{33}$ Iowa Territorial Library, 1841 Report, 1841. 
gress ... library is entirely destitute of late works which have been issued from the press on the subject of education and other subjects of a general nature....34

Three years later, Patterson quoted himself almost exactly on the lack of appropriations for the increase of the library, which resulted in increases only through books received from Congress and other states. He numbered the volumes at about 1670 , onethird of which were law books.

Again he said the "library is entirely destitute of late works ... the library was purchased in 1839 and up to this time the state has not made any addition to it." He suggested an appropriation of $\$ 1,000$ to make the library "respectable and an honour and ornament to the state: such appropriation with a small yearly appropriation of two hundred dollars would keep it up with the progress of the age." ${ }_{35}$

In 1851 , there were slightly over a hundred more volumes than in 1839. If all added volumes were exchanges, then the list of purchases suggested by the library committee to the third legislative assembly in November, 1840, must have been ignored.

What is striking about the library? It was Iowa's first "public" as well as territorial and state library. Lucas wanted to base it upon works that would be standard in a public library, and be made available to more than just legislators. And if the "key legend" is true, there was open access to the collection, for a time at least.

There was no provision for fiction. Some fiction which appeared in collected works of authors was classified under "Miscellaneous." As far as I can determine, all the books in the Old Capitol Library were in English. Cosmos, Plutarch's Lives, and the works of Tacitus were all translations of the originals.

Many of the books are still important today. A check of Dickinson's The World's Best Books from Homer to Hemingway, Grolier Club's One Hundred Books Famous in English Literature . . . and Grolier's One Hundred Influential American Books Printed Before 1900 shows dozens of the titles which were in Old Capitol Library.

Have You Read 100 Great Books? brings together lists of out-

${ }^{34} 1848$ Iowa House Journal, 232-233.

${ }^{35} 1851$ Iowa State Senate Journal, 140. 
standing books, and then takes all its lists, eliminates duplication, and comes up with a list of " 1500 great books." From the " 1500 " is culled " 100 great books." Books in Old Capitol Library that made the list are: Boswell's Johnson, the Bible, Cellini's Autobiography, Don Quixote, Federalist, Faust, and Malthus' Population.

As one might expect, the authors were mainly men, and overwhelmingly either American or British. They came from all walks of life, and included in their ranks five U.S. presidents: George Washington, John Adams, John Quincy Adams, Thomas Jefferson, and James Madison. Ten women writers were represented: Mary Barney, Maria Edgeworth, Stephanie Genlis, Elizabeth Hamilton, Mary Martha Sherwood, Hester Piozzi, Lady Mary Montague, Susanna Moodie, Hannah More, and Julia Pardoe. Mary Barney was the only American of the group.

Many of the authors were living about the time of the American Revolution. Their writings give a priceless picture of the period.

More significant (from the standpoint of selection) is the fact that over one hundred of the authors were still living in 1839. This indicates a regard for contemporary literature, rather than a dependency on past culture and "proven" classics. Two authors lived into the twentieth century. One was Frederick Saunders, a Londoner who came to America in 1837, and helped consolidate libraries into the New York Public Library. ${ }^{36} \mathrm{He}$ died in 1902. An author who survived until 1903 was Frederick Olmsted, Connecticut-born landscape architect, and chief architect of Central Park and the Chicago World's Fair. ${ }^{37}$

One author, Washington Irving (named for George Washington) was born in 1783 when the American Revolution ended, and died in 1859 at the start of the Civil War. The popular Irving, first great humorist, satirist, and hoaxer this country produced, was represented by 15 volumes of his works in Old Capitol Library.

\section{The Meeting of the Past and Present in the Library's Restoration}

On November 1, 1972, I took the list "Acquistions of the Ter-

${ }^{36}$ Dictionary of American Biography, 16, 381-382.

${ }^{37}$ Ibid., 14, 24-27. 
ritorial and State Library of Iowa"* which had been compiled by Steven K. Dawson and Margaret N. Keyes in July, 1971, and headed for the public catalog of The University of Iowa Main Library. After checking all cards under "Bibliography," "Iowa," and "Libraries-Iowa," a three page list was compiled of possible sources of information about either Old Capitol, the library in Old Capitol, or the titles in that library. Someone had once told me that "only librarians read the fine print" on catalog cards. This came to mind when noting the words "Catalogue of the Territorial library made by Librarian Parvin in 1839" at the bottom of a card for Johnson Brigham's A Library in the Making. Not having been aware there was any catalogue, this was an exciting find.

During the next few weeks, I combed Annals of Iowa, Iowa Journal of History and Politics, The Iowan, Palimpsest, Iowa Library Quarterly, Iowa Historical Record, Iowa Library Commission Reports, and Iowa State Library Reports. A search of available articles and reports revealed that a second catalogue (1845) had been published. The Iowa Masonic Library had copies of both catalogues, and a xeroxed copy of the 1845 one was obtained.

At this point, the 1839 catalogue reprint, the copy of the 1845 catalogue, Luella Wright's article "Iowa's oldest library," and the Dawson and Keyes list were compared. This information was sifted, and transferred onto 546 cards.

The next source checked was Orville Roorbach's Bibliotecha Americana. This covers American publications during the years 1820-1861. Seventy-two per cent of the Old Capitol Library titles were in this book. It was helpful to find that Roorbach had a classification of Law similar to that of Parvin's.

Over a hundred first names of authors were picked up from this bibliography. Believe it or not, the original 1839 catalogue often listed one name and a shortened title, or in some cases, just the title. "Smith on Fever" or "Minutes of Conference" or "British Cattle" are examples. Some listings under Poetry were simply: "Gay," "Milton," "Pope," or "Swift." Numbers of volumes were noted in each case.

*This list based upon Territorial and State vouchers of the $1840-1857$ period for the purchase of books and other publications for the library. 
Further information on titles was sought in Truebner's Bibliographic Guide to American Literature, Wemyss' The General Guide to Rare Americana . ... Evans' American Bibliography, Shaw and Shoemaker's American Bibliography: A Preliminary Checklist. Shoemaker's Checklist of American Imprints, and Sabin's Dictionary of Books Relating to America, from its Discovery to the Present Time.

In Adolf Growoll's Book-Trade Bibliography in the United States in the Nineteenth Century, a reprint of the first book trade catalogue (1804) published by American booksellers was checked. This interesting and rare source of information is a classified list of 1,338 books, ranging from "Physics" to "Singing Books."

Since the Old Capitol Library had a buying spurt in 18521855, the ads in Norton's Literary Gazette and Publishers Circular, which covered the book trade from 1851 to 1855 were studied. No serious checking had been done on the law titles since Roorbach, and a trip was made to the University of Iowa Law Library in order to check their catalog and the catalogs of the Harvard and Columbia Law Libraries.

Later, all Iowa legislative journals from 1838-1857, and all laws of Iowa passed during the same time period, were checked for references to the library. Cards were compared with the 1872 and 1889 catalogs of the Iowa State Library, and then with Library of Congress catalogs.

Finally, I returned to the University of Iowa Library's main catalog. Many of the Old Capitol Library titles were there. It was now February, 1973; by accident, the first book was found: George Putnam's The World's Progress: A Dictionary of Dates. 6th ed., 1852. A total of six titles (19 books) were found in The University of Iowa Main Library. A search of the Law Library on campus revealed others.

There was concern about preservation of the new Old Capitol Library. On the advice of Leeta Berry, University Library book repair specialist, I contacted Nathan Stolow, director of the Canadian Conservation Institute. In March, Mr. Stolow was kind enough to respond with specific suggestions and a reprint of one of his articles.

On April 20, 1973, I made the first trip to the Iowa State Li- 
brary* in Des Moines. The earliest accession book for the library was found. ${ }^{38}$ This accession book dated from August, 1875, and was completed in May, 1877. The book numbers almost six hundred pages, and contains 15,262 entries.

The accession book had information on about 220 titles that were in Old Capitol Library. These were mainly in the fields of history, politics, and science. Some titles were marked "transferred to ..." Good luck-the information and numbers on the Putnam book matched the book already found. Bad luck-on page 111, \#2848-50, the three volume set of Raynal's A Philosophical and Political History of the Settlements and Trade of the Europeans in the East and West Indies was marked "sold to A. H. McVey-\$2.00."

On May 30, 1973, Dale Bentz, University Librarian, whose continuing interest and support has smoothed the way for our project, offered space in a vault in the Special Collections Department for the beginning collection.

In June, after more searching in Des Moines and Iowa City libraries, lists were compiled of the found books. Results showed that in Iowa City, three libraries had books believed to have been in Old Capitol. The main and law libraries at The University of Iowa had a total of 13 titles (seventy-five books), and the State Historical Society of Iowa had two titles (five books).

In Des Moines, the Iowa State Library had 175 titles, the State Law Library: 109, the State Medical Library: fifteen, and the State Department of History and Archives: 4 books and 4 maps. Missing were 261 titles. The number of titles will not add up to 546 , because some sets were broken, and their titles appear on more than one list.

At this time, an interesting story about library books was heard from William Graf, Iowa City book dealer. This is the tale as he relates it: The Lee bookstore of Iowa City had some books from Old Capitol. The Ries bookstore got the books from the Lee bookstore.*

*Iowa State Traveling Library. The word "Traveling" was dropped as of July 1. 1973.

${ }^{38}$ Iowa State Library, Des Moines, Numerical Record, August 9, 1875.

*A check into early Iowa City directories reveals that in 1857 there was a William Lee store, in 1875 a James Lee bookstore. In 1891, Lee and Ries were the "Pioneer Booksellers"; in 1904, Lee and Ries had separate stores; in 1920, there 
Mrs. Ries sold "all her things" to an antique dealer "six or seven years ago." Mr. Graf purchased several dozen of these books from the dealer. These were remembered to be state and government reports, and were marked in pencil "Old Capitol" or "Iowa State Library" on preliminary leaf or title page. Some were in bad shape and were thrown away; others Mr. Graf sold. ${ }^{39}$

On July 23 and 24, the lists of "found" books were delivered to the seven libraries. An accompanying letter requested that the libraries participate in Iowa's "appointment with history" with the donation of these books to the Old Capitol Restoration. On the 24th, The University of Iowa Main Library agreed to share in our project, and this was a red-letter day!

In August, our missing list was circulated to ninety-two libraries and institutions in Iowa, plus the Library of Congress in Washington, D.C. It was also sent to a few individuals who had expressed an interest.

On September 18, 1973, the State Historical Society of Iowa transferred their five books, and these were the first actually catalogued and received into the restored collection.

When trying to look back, and credit persons who were central in forming the character and fostering the development of Iowa's first library, one must mention the following: Robert Lucas for selection; Theodore Parvin for selection, organization, and the first catalogue; Morgan Reno for bringing it to Iowa City and for the second catalogue; Governor Stephen Hempstead for the purchase of over 250 volumes of miscellaneous books (including a 33 volume set of James Fenimore Cooper's works for $\$ 24.00$ !); ${ }^{40}$ Librarian Martin Morris for the purchase of $\$ 500$ worth of law books; and Governor James Grimes for the purchase of 101 law books and 303 miscellaneous books.

As far as capturing its history for the rest of us, one must mention Ada North, who contributed an historical sketch in 1875, and Johnson Brigham whose "Pioneer History of the Territorial

was a Ries bookstore. In 1952, Ries was listed, but the store was not in the 1954 directory.

${ }^{39}$ Conversation with William Graf, June 28, 1973.

${ }^{40}$ Governor Hempstead spent $\$ 486.52$ on the books. They are listed, along with some sizes and physical descriptions, on pages 310-311 of the 1853 Iowa Senate Journal. 
and State Library of Iowa" (published in Annals of Iowa in 1912 and 1913 and later reprinted as A Library in the Making) brought together library legislation, the reprint of the first catalogue, and various reports, some of them never before published.

The federal government not only granted $\$ 5,000$ for the library in 1838 - in 1839, it gave the land on which Old Capitol stands. ${ }^{41}$ In 1973, the Iowa American Revolution Bicentennial Commission awarded a \$5,000 grant for the Old Capitol Library's restoration. ${ }^{42}$

Now the books will be collected, restored, and organized for use according to Theodore Parvin's classification. With the facilities of The University of Iowa, its fine libraries, and the support of the Old Capitol Restoration Committee and the Director of Research for the Old Capitol Restoration, Margaret N. Keyes, the library project continues on schedule.

On July 4, 1976, the restored Old Capitol will be open to the public in celebration of the bicentennial anniversary of our country's founding. The books, returned to the library where they were kept and used by citizens of a century ago, will be part of the recreation of one aspect of Iowa's history.

${ }^{41}$ U.S. Statute III, Chapter 77, United States Statutes at Large, 5, 330.

${ }^{42}$ Iowa City Press Citizen, June 23, 1973, 9A. 
Copyright of Annals of Iowa is the property of State of Iowa, by \& through the State Historical Society of Iowa and its content may not be copied or emailed to multiple sites or posted to a listserv without the copyright holder's express written permission. However, users may print, download, or email articles for individual use. 